\title{
A LEITURA LITERÁRIA DE A HORA DA ESTRELA: UM PERCURSO DE ENCONTROS E DESCOBERTAS
}

\section{LITERARY READING OF THE HOUR OF THE STAR: A JOURNEY OF ENCOUNTERS AND DISCOVERIES}

\author{
Sarah Vervloet SOARES ${ }^{1}$ \\ Neide Luzia de REZENDE ${ }^{2}$
}

\begin{abstract}
Resumo: O presente artigo apresenta um relato de experiência de leitura literária, realizada no primeiro ano do ensino médio, do Instituto Federal do Espírito Santo (IFES - campus Piúma) e, ainda, discute alguns aspectos que se tornaram relevantes durante essa prática. Por meio de aulas transformadas em encontros, o projeto de leitura da obra A hora da estrela (1977), de Clarice Lispector, teve o objetivo de aproximar os alunos da prática da leitura. Assim, a leitura literária, a mediação de leitura, a interação com a biblioteca escolar, a produção do portfólio de leitura e a didática de literatura são os principais pontos de interesse deste artigo. Para tanto, dialogaremos, principalmente, com Colomer (2007), Petit (2008, 2009, 2013), Jauss (1994), Rouxel (2013) e Rezende (2013). A leitura literária, neste caso, resultou na abertura para novas possibilidades de ensino e aprendizagem e provocou nos estudantes maior autonomia para se expressarem, emitirem opiniões a respeito das leituras, ou seja, trata-se de um momento em que eles se reconheciam como leitores de literatura.
\end{abstract}

Palavras-chave: Leitura literária. Portfólio de leitura. Mediação de leitura. A hora da estrela. Clarice Lispector.

Abstract: This paper reports on a literary reading experience in the first year of high school, at the
Federal Institute of Espírito Santo (IFES - campus Piúma) and discusses some aspects that became
relevant during this practice. Through lectures turned into meetings, the reading project of The hour of
the star (1977), by Clarice Lispector, aimed to bring students closer to reading practices. The main
points of interest in this paper are the literary reading, the reading mediation, the interaction with the
school library, the reading portfolio production and the literature teaching. In order to do this,
discussions are mainly based on Colomer (2007), Petit (2008, 2009, 2013), Jauss (1994), Rouxel (2013)
e Rezende (2013). The experience resulted in the opening of new teaching and learning possibilities and
provoked in the students a greater autonomy to express themselves, to express their opinions regarding
the readings; in other words, it was a time when they recognized themselves as literature readers.

Keywords: Literary reading. Reading mediation. Reading portfolio. The hour of the star. Clarice Lispector.

\footnotetext{
${ }^{1}$ Doutoranda em Educação (USP) e professora no Instituto Federal Fluminense (IFFluminense - campus Bom Jesus. E-mail: sarah.soares@iff.edu.br

${ }^{2}$ Doutora em Educação pela Universidade de São Paulo; professora da Faculdade de Educação da Universidade de São Paulo. Coordena o Grupo de Pesquisa Linguagens na Educação (FEUSP) e integra o GT Literatura e Ensino da ANPOLL. E-mail: neirez@usp.br
}

Revista Graphos, vol. 21, n²1, 2019 | UFPB/PPGL | ISSN 1516-1536 


\section{Apresentação}

Pretende-se, neste texto, descrever uma série de experiências de leitura ${ }^{3}$ realizadas a partir da obra A hora da estrela, de Clarice Lispector (1977), e discutir alguns aspectos que se tornaram relevantes durante essa prática. Embora se considere que a leitura faça parte de um longo percurso, pessoal e - ao menos neste caso - coletivo, em que as condições de tempo e espaço são singulares; quando está inserida no contexto escolar, as variáveis para esse processo acontecer tornam-se ainda mais vastas. Neste contexto específico, havia a exigência institucional de avaliação formal, fato este que levou o projeto a um produto final, chamado Portfólio de Leitura.

Em princípio, no contato com quatro turmas de primeiro ano do ensino médio, procurei compreender as percepções dos alunos no que diz respeito à leitura literária em sala, ou seja, iniciei um amplo diálogo para encontrar os canais de comunicação e traçar seus perfis de leitores e leitoras de literatura. A quase unânime dificuldade de lidar com a "linguagem complexa" das obras literárias propostas em sala abriu caminho para a leitura coletiva e, assim, iniciou-se o percurso de leitura do último romance de Clarice. A opção pelo livro partia de duas motivações: os aspectos relativos às questões da subjetividade, ao tema do feminino, à especificidade histórica, ao trabalho com a linguagem e com a metanarrativa etc.; e minha identificação pessoal com a obra de Clarice Lispector. Se a primeira motivação nos leva a um rigor pedagógico necessário para engendrar um projeto de leitura literária na sala de aula, a segunda diz respeito ao que não se pode desvencilhar do trabalho com a literatura, que é a escolha do corpus, seu caráter subjetivo e definidor. Isso significa desenvolver a disponibilidade para oferecer obras de qualidade, com um tanto de intuição, é claro - principalmente quando se trata de certa dificuldade de decifração do público -, mas também com um tanto de cuidado, a fim de que não nos deixemos levar pelos textos menos exigentes, acreditando "agradar" o público. O que está em jogo, nesse momento, é abrir caminhos para os sentidos dos textos, que é diferente de apresentar os sentidos já desenhados, prontos.

A leitura de $A$ hora da estrela foi o verdadeiro foco das atividades, porém, funcionou como aquilo que Teresa Colomer (2007) entende como uma das funções do ensino literário na escola, que é "ensinar o que fazer para entender um corpus de obras cada vez mais amplo e complexo" (p. 45). Ler a novela clariceana pressupunha familiarizar-se com boa parte da obra,

\footnotetext{
${ }^{3}$ A prática aqui descrita aconteceu no ano de 2014 e suas reflexões surgiram e desenvolveram-se ao longo do tempo. O grupo que tornou possível a realização desse projeto era formado por quatro turmas do primeiro ano do ensino médio, do Instituto Federal do Espírito Santo (IFES), localizado no campus Piúma/ES.
}

Revista Graphos, vol. 21, n²1, 2019 | UFPB/PPGL | ISSN 1516-1536 
pois ela não é um fragmento, é uma continuação de percurso artístico, cujos sentidos podem ser aprofundados a partir desses movimentos de leitura em sala. E o sujeito que medeia essa leitura significativa, entre outras coisas, é quem ensina o que fazer com a própria leitura, a quem Michèle Petit (2008) chama de "iniciador":

[...] o iniciador do livro desempenha um papel-chave: quando um jovem vem de um meio em que predomina o medo do livro, um mediador pode autorizar, legitimar, um desejo inseguro de ler ou aprender, ou até mesmo revelar esse desejo. E outros mediadores poderão em seguida acompanhar o leitor, em diferentes momentos de seu percurso. (p. 148).

A ideia mesma de percurso de leitura remete à mudança de ótica do "ensino de literatura" para "educação literária" (COLOMER, 2007, p. 32) ou "leitura literária" (REZENDE, 2013, p. 106), sugerindo um processo mais intenso e integrado à escola, o que pode ser percebido naquilo que reverberou das leituras em atividades posteriores, dentro e fora da escola, e na própria materialidade delas presente nos portfólios. Um exemplo dessa integração leitura-escola parece bastante óbvio, pois se trata da parceria da biblioteca com as atividades ao longo de todo projeto, mas nem sempre esse é um espaço que funciona como extensão da sala de aula. Alguns fatores mostraram-se favoráveis a essa parceria, como a adesão da bibliotecária, o apoio e a cooperação durante as aulas e a ideia de pertencer ao projeto, ou seja, a profissional da biblioteca reconhecer-se como agente de mediação de leitura e promotora da literatura.

\section{Encontros possíveis na leitura: aproximações, identidades, recepções}

Antes de iniciar a leitura integral da obra, tinha a pretensão de tornar possíveis alguns encontros - nome dado às etapas do projeto. Dessa forma, a começar pela biblioteca, inaugurada coincidentemente com o nome de Clarice Lispector, o encontro com as obras da autora disponíveis na escola proporcionou discussões pertinentes ao ambiente e à bibliotecária. Iniciava-se um importante debate entre a vida e a obra, que perpassou os outros momentos de leitura. Abaixo, apresenta-se o roteiro resumido desses encontros:

1) Na biblioteca: exposição fixa de obras da autora, breve apresentação sobre sua biografia e bate-papo com a bibliotecária;

2) Clarice contista: leitura coletiva em sala do conto "O primeiro beijo", de Clarice Lispector";

${ }^{4}$ LISPECTOR, Clarice. O primeiro beijo. In: Felicidade Clandestina: contos. Rio de Janeiro: Rocco, 1998, p. $157-159$.

Revista Graphos, vol. 21, n 1, 2019 | UFPB/PPGL | ISSN 1516-1536 
3) Na televisão: entrevista concedida pela escritora no canal TV Cultura, em 1977 (disponível no YouTube) - trechos assistidos em sala e discussão pós-sessão;

4) Na internet: apresentação, em sala, de frases de Clarice que se tornaram conhecidas nas redes sociais;

5) Dedicatória de A hora da estrela e de seus 13 títulos possíveis ${ }^{5}$ : leitura, em sala, da dedicatória e de seus títulos, que explicam algumas motivações para a escrita do romance e momentos da história;

6) Com o narrador, Rodrigo S.M.: início da leitura, em sala ou em espaços da escola, como a biblioteca, o pátio, o laboratório de informática etc.;

7) Com Macabéa: a chegada à personagem principal e suas características;

8) Nas músicas: compreensão em sala de duas músicas, "O nome da cidade", de Caetano Veloso; "A hora da estrela", de Pato Fu;

9) No filme: trechos do filme (dirigido por Suzana Amaral, em 1985) assistidos em sala, com discussão ao final;

10) No portfólio: entrega do material produzido ao longo dessas etapas, com apresentação em grupo.

Os encontros de leitura faziam ecos, uns nos outros, nas demais aulas, nas outras turmas e, claro, na biblioteca. Maria Helena de Barros (2006) lembra que o professor e o bibliotecário, trabalhando articulados, fazem do ensino mais coerente, mais voltado ao cuidado e ao interesse pela formação de leitores. Com a exposição fixa dos livros de Clarice na biblioteca, outros alunos tiveram também contato com a obra e, ao final do projeto, o sistema da biblioteca contabilizava um crescimento de mais de cem por cento no empréstimo de livros da autora (levantamento realizado pela bibliotecária no final daquele ano).

Em seguida, foi realizada, em sala, a leitura do conto "O primeiro beijo", também de Clarice Lispector, a fim de que houvesse a introdução aos aspectos estéticos dessa escrita, ou seja, uma aproximação gradual do foco da leitura. Cada trecho do conto foi recortado em pedaços de papel, distribuídos em seguida para os alunos, que se sentavam em círculo. A leitura, circularizada, era realizada em voz alta, um a um, enfatizando o suspense da história: que tipo

\footnotetext{
${ }^{5}$ Os 13 títulos são: A culpa é minha / A hora da estrela / Ela que se arranje / O direito ao grito / Quanto ao futuro / Lamento de um blue / Ela não sabe gritar / Uma sensação de perda / Assovio no vento escuro / Eu não posso fazer nada / Registro dos fatos antecedentes / História lacrimogênica de cordel / Saída discreta pela porta dos fundos.
} 
de beijo era aquele? E, ao final, quando se depararam com seu desfecho, apresentaram surpresas, frustrações, estranhamentos. Alguns alunos solicitaram a segunda leitura para compreenderem ou tirarem a prova - “será mesmo isso que eu estou pensando?". E entenderam que o conto de Clarice realizava certo abalo às suas expectativas. Os alunos perceberam que estavam diante de uma forma diferente de narrar porque "ela utiliza palavras e frases mais difíceis para dizer uma coisa simples, não exatamente simples, mas que todos nós sabemos que essas coisas existem", como afirmou um aluno naquele momento.

Apesar de não se poder dizer que a partir daí os estudantes estavam preparados para a literatura clariceana, mesmo porque parece impraticável determinar isso, esse segundo encontro já ditava a mim algumas questões relativas ao ritmo de leitura em sala, às expectativas dos leitores, às estratégias necessárias, entre outros. Colomer (2007) aponta para essa "necessidade de informação sobre o contexto das obras". Assim, "Os alunos podem aceitá-lo se lhes demonstramos que é útil, se sentirem a necessidade de perguntar e saber; uma necessidade que faz parte da curiosidade inata dos seres humanos e que a escola deve incentivar” (p. 71).

Uma vez mais, a ideia de convidar à obra por meio de um caminho de contextualização, como que ditando onde se deve tatear no ato da leitura, foi significativo para desenvolver uma certa atração pelo que estava se propondo: não só a obra em si, mas a trajetória que ela viria a criar, com a construção do portfólio como fio condutor. Com isso, o terceiro encontro foi realizado na sala de aula e tratava-se de uma sessão para assistir a trechos da entrevista que Clarice Lispector concedeu à TV Cultura, em 1977. A autora conta que está finalizando A hora da estrela e comenta alguns aspectos que os leitores poderão encontrar em sua obra. A maioria dos alunos arguiu espanto diante da figura emblemática da autora, mas pode-se dizer que sua "aparição" diminuiu a distância que há nessa figura inacessível que é o autor. Neste momento, é possível perceber a identificação, misturada com encantamento, que gerou comentários no próprio portfólio, como: “Clarice deixa incógnitas ao longo da história, permitindo que a gente reescreva a história imaginariamente e compare com a história da autora também" e "(...) te senti com o coração, com o pulmão e até com o dedinho do pé, o seu melhor está guardado dentro de mim em um baú trancado a 7 chaves para ninguém te roubar”.

Michèle Petit (2013) questiona-se se estamos diante de uma identificação, de fato, quando a leitura oferece uma imagem fascinante ao leitor, cujo risco é seguir os piores desvios do herói ou da heroína. Contudo, Petit chama atenção para a busca pela palavra, pela simbolização, a que nos entregamos sempre em nossas leituras. O que ocorre com os adolescentes é reconhecer o texto que fala sobre eles:

Revista Graphos, vol. 21, n 1, 2019 | UFPB/PPGL | ISSN 1516-1536 


\begin{abstract}
Essas frases, esses fragmentos de textos, funcionam como insights, como tomadas de consciência súbitas de uma verdade interior, como esclarecimentos sobre uma parte de si mesmos até então desconhecida. Isso permite a eles decifrarem sua própria experiência. É o texto que "lêe" o leitor, que sabe muito sobre ele, sobre regiões nele que ainda não haviam sido exploradas. O texto, de maneira silenciosa, vai liberar algo que o leitor tem dentro de si. E às vezes o leitor encontra ali a energia, a força para sair de um contexto em que estava preso, para se diferenciar, para se libertar dos estereótipos aos quais estava preso. (p. 46).
\end{abstract}

A dedicação para que a obra se tornasse "acessível" aos alunos, de modo que eles pudessem encontrar pontos de "encontro" com suas próprias consciências e experiências, tinha uma motivação principal, percebida naquelas primeiras conversas sobre leitura literária. Os encontros pré-leitura de A hora da estrela pretendiam aproximar alunos e obra, por meio da linguagem, do contexto, das questões de Macabéa, entre outros. É como se, a cada encontro, fosse possível afirmar aos jovens leitores: "vejam como vocês podem atingir Clarice, ler sua obra, vejam como ela pode ser inteligível”.

Efetivamos, nessa esteira, o quarto encontro de nosso percurso - a descoberta de que Clarice estava mais perto do que imaginavam, pois suas frases icônicas povoam o mundo das redes sociais, ainda que nem sempre sejam atribuídas a ela ou conferem à sua autoria frases de outros autores. Por isso, apresentei as frases que realmente se encontram nos seus contos, crônicas, cartas e romances, como "Liberdade é pouco. O que eu desejo ainda não tem nome"6. Com surpresa, percebi ainda mais o apreço dos alunos por essa escritora conhecida na internet por seus fragmentos. A discussão acerca de autoria e de plágio, além da busca por caracterizações dessa escrita, ampliou o tempo destinado a esse encontro. Os alunos reconheceram a inclinação de Clarice às questões subjetivas ou, como disseram eles, "fillosóficas". Portanto, transformaram esse encontro em um momento de experimentação da linguagem, pedindo a mim que refizessem as frases da autora segundo suas próprias questões, como a frase que o aluno escreveu na lousa: "A felicidade só é real quando compartilhada", com a assinatura de "M. Lispector" (inicial de seu próprio nome). No final desse dia, muitos status pessoais na internet haviam mudado para frases de Clarice Lispector e muitos sobrenomes também - nas redes sociais, surgiram Amanda Lispector, Junior Lispector, Alessandra Lispector etc.

Os próximos três encontros foram de maior duração: era, finalmente, a leitura integral da obra. Eles aconteciam, além da sala de aula e da biblioteca, em outros espaços até então inéditos de leitura, como sob as árvores do pátio da escola. Inicialmente, foi feita a compreensão

\footnotetext{
${ }^{6}$ LISPECTOR, Clarice. Perto do Coração Selvagem. Rio de Janeiro: Nova Fronteira, 1980, p. 74. Revista Graphos, vol. 21, n 1, 2019 | UFPB/PPGL | ISSN 1516-1536
} 
tanto da dedicatória de Clarice, quanto dos 13 títulos que a autora havia proposto ao livro. Isso porque são elementos da obra que dão o tom ou até mesmo integram o romance, ainda que se encontrem à parte na sua totalidade. Assim, afirma a escritora que "Trata-se de livro inacabado porque lhe falta resposta" (LISPECTOR, 1995, p. 20), deixando o leitor preparado para uma quebra de expectativas.

Sob a ótica da Estética da Recepção, Hans Robert Jauss (1994) vai dizer que o leitor é responsável pela recepção da obra, tornando-se destinatário dela, o que permite o diálogo com a literatura. No entanto, essa imagem de leitor projetada por Jauss não se trata de um leitor comum, mas de uma comunidade de leitores que compartilha um horizonte de expectativas, em espaço e tempo determinados. Nesse contexto, é imprescindível compreender que esses alunos, em específico, devido a um histórico de experiências de leituras de best sellers, esperavam uma história cuja trama tivesse muita ação e cujo desfecho apresentasse final feliz. Isso porque havia indagações como "por que temos que ler este livro e não outro?”. E as opções que me apresentavam ficavam, em sua maioria, nos best sellers. Cada encontro feito com Macabéa e, antes disso, com Rodrigo S.M. - o narrador que é escritor -, transformava-se em questionamentos: “por que ele faz isso com Macabéa? Por que ele é tão mau? Coitada dela!” e, mais adiante: "essa história é um pouco triste e monótona" e, ainda: "Macabéa não merecia morrer assim. Ela merecia ser feliz ao menos uma vez na vida".

Ainda no intento de Jauss (1994), encontramos a ideia de "leitor-mediador" (p. 25), por meio do qual os aspectos estético e histórico se encontram e, com eles, vai tateando a obra literária, pois ela não é um campo vazio, assim como o próprio leitor não é também um vácuo, o qual a literatura vai preencher com suas novidades. Nesse sentido, há um saber baseado em experiências anteriores, inclusive de leituras, cujas percepções construídas geram expectativas no leitor. Jauss pontua que a obra que contraria esse horizonte de expectativas possui bastante valor. Pode-se dizer, então, que o leitor realiza a "atualização" da obra (p. 25).

Quando adentramos a novela clariceana, a leitura começou a ser feita de forma integral em sala. No entanto, sabemos que o tempo escolar, muitas vezes, é desfavorável às atividades de leitura e de escrita, sendo necessário buscar meios para que, mesmo assim, elas possam acontecer. Nesse sentido, ao dividir o livro em oito seções, busquei empreender metas de leitura, a fim de que houvesse um controle e objetivos a serem atingidos, pressupondo que em sala não seria possível realizar a leitura completa de cada seção. Como o livro não é dividido por capítulos, a divisão foi didática, feita a partir de pausas mais ou menos visíveis na história. 
Dessa forma, a leitura de uma parte era iniciada na escola e finalizada em casa ou vice-versa, com intervalos para a produção do portfólio.

Os alunos sentavam a minha volta e acompanhavam a leitura em seus livros, celulares ou tablets. É importante destacar que o acesso ao objeto livro não era simples e, com isso, sua disponibilidade digital foi uma saída e, também, uma surpresa, já que houve facilidade de manuseio e leitura por meio dessas plataformas. Além disso, ainda que minha função de mediadora tenha sido destacada desde os primeiros encontros, tornou-se cada vez mais comum que um ou outro aluno pedisse a palavra para destacar algum trecho do livro que julgou interessante. Um tema puxava outro: a realidade social da nordestina retirante, o trabalho com a linguagem, o sensível da palavra, o nada e o vazio diante da miséria humana, o feminino descoberto, a marginalização das classes oprimidas etc.

Bayard (2007) procura explicar que, mais que o próprio livro, é importante a percepção que se abre a partir do primeiro contato com ele, que é a ampliação do universo cultural segundo um conjunto de discursos a propósito dos próprios livros. O intercâmbio de ideias e vozes nas rodas de leitura talvez servisse como um suporte para aqueles que não conseguiam fazer as leituras sistemáticas; eles, então, podiam beber desses discursos e até se motivarem a, finalmente, fazer as leituras. Como no caso de uma aluna que não tinha um exemplar do livro e lia, então, por meio do computador. De tanto que insistiu, sua mãe foi até a escola para me pedir o livro emprestado. Ao final da leitura, a aluna não queria devolver meu exemplar, de modo que sua mãe insistiu em pagar pelo livro para que a menina o tivesse como seu, mesmo após o término das aulas.

É possível dizer que o percurso de $A$ hora da estrela - contando também com a análise das músicas "O nome da cidade", de Caetano Veloso; "A hora da estrela", de Pato Fu, durante a leitura; e do filme homônimo, dirigido por Suzana Amaral, após a leitura - faz parte de um "acolhimento" para compartilhar as angústias que nascem desse contraste relativo ao horizonte de expectativas desses leitores. As rodas de leitura e a discussão da obra promoviam a autoridade dos alunos enquanto leitores, porque, uma vez lida a obra, eles se mostravam autorizados a falar sobre ela - e falar sobre ela significava criticar, dar sugestões, emitir opiniões, dentro de sala, fora dela, nos corredores da escola e nas redes sociais.

\section{Para além do portfólio de leitura}

O portfólio de leitura foi um objeto confeccionado ao longo dos encontros descritos. Tal como as metas de leitura, o portfólio continha algumas diretrizes e prazos, de maneira que as 
impressões ao longo desse processo fossem registradas, e não houvesse acúmulo das atividades no final do ano letivo. Desse modo, a instrução para elaborar o portfólio dava-se da seguinte forma:

\section{Portfólio de leitura - A hora da estrela, de Clarice Lispector}

- Grupos de 4 a 5 pessoas.

\section{Seu portfólio deve conter:}

- Capa, folhas organizadas, nomes e turma do grupo;

- Comentários do grupo sobre cada parte do livro (com, no mínimo, 5 linhas e, no máximo, 10 linhas);

- Contribuições individuais: anotações, fotos, ilustrações e/ou textos inspirados no livro, na autora, na literatura de modo geral e nas aulas;

- Um texto de, no mínimo, 12 linhas, no qual o grupo responda à questão: "por que ler A hora da estrela?";

- Fichamento completo sobre o livro.

Seu portfólio pode conter: fotos, desenhos, recortes, criações, entre outros.

Seu portfólio será avaliado por: organização e conhecimento sobre a obra.

Com efeito, essa produção laboral antevia a sistematização de uma leitura literária, vislumbrando aquele leitor que lê com o lápis em punho e o olhar curioso para prosseguir com suas descobertas. O caráter de diário atribuído ao portfólio colaborava para o entrosamento dos grupos, o envolvimento dos alunos e o despertar para um livro, antes, estranho, como afirma um grupo em seu portfólio: “(...) o desenvolvimento do livro é complexo e muito culto, e é para algumas pessoas uma história conturbada. $\mathrm{O}$ decorrer da história nos faz refletir sobre vários aspectos do dia a dia que, às vezes, passam despercebidos diante de nossos olhos". Abaixo, um exemplo de uma página de um portfólio finalizado: 
Imagem 1 - Exemplo de uma página de portfólio

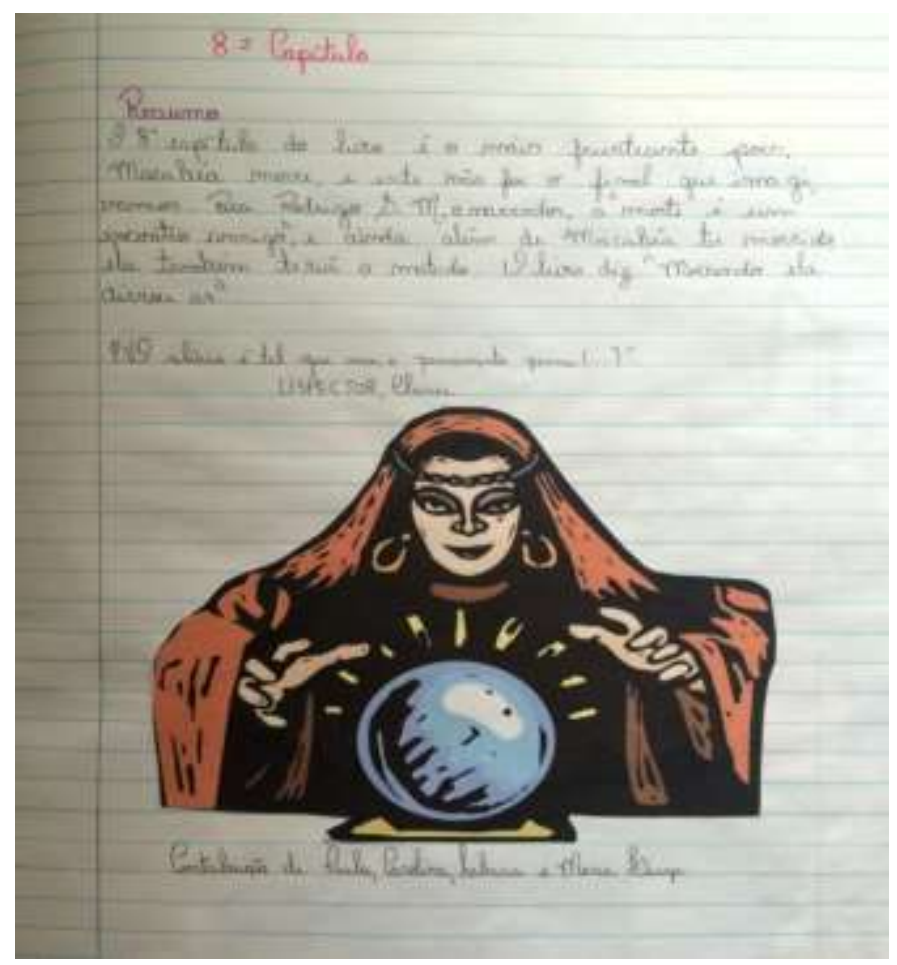

Fonte: da autora.

Nota: O texto diz: "O $8^{\circ}$ capítulo do livro é o mais frustrante pois Macabéa morre, e este não foi o final que imaginamos. Para Rodrigo S. M., o narrador, 'a morte é um encontro consigo', e ainda, além de Macabéa ter morrido, ela também teria o matado. O livro diz: 'Morrendo ela virou ar'. 'O silêncio é tal que nem o pensamento pensa' (LISPECTOR, Clarice)".

Como foi dito, a produção dos portfólios de leitura tinha uma motivação maior, que é a necessidade de avaliação escolar. O essencial da experiência pessoal de leitura desses adolescentes, no entanto, não está registrado nas folhas do portfólio: cada qual com suas singularidades e descobertas, há aspectos pontuais que nos dão pistas disso, como as postagens espontâneas nas redes sociais sobre a fruição da leitura, os "boatos" que corriam na escola e provocavam em alunos de outras séries o desejo pela leitura do romance, a demanda dos estudantes por mais leituras "parecidas", como eles mesmos diziam, entre outros. Ademais, ao refletir sobre as avaliações de leitura, Colomer (2007) explica que "a formulação de avaliações só pode chegar através das atividades que favorecem um tempo de reflexão e expansão da recepção própria, por um lado, e um tempo de exploração conjunta de significado, por outro" (p. 150). Como a produção do portfólio foi realizada durante todo o processo de leitura, compreende-se, portanto, que o produto não é o mais importante, mas o que foi realizado nesse tempo de reflexão, expansão e exploração. 


\section{Abertura para outras possibilidades educativas}

Um projeto que vise a uma leitura mais plausível na perspectiva dos alunos tem a ver, sem dúvida, com uma concepção da própria noção de leitura e de leitores. Até então, embora não houvesse, para mim, questões muito claras dessa natureza àquele momento, o incômodo de perceber a indiferença e quase recusa dos alunos às leituras escolares, e constatar que isso era, muitas vezes, lugar-comum das queixas dos meus colegas professores, foi o começo para levantar algumas hipóteses com relação a nossas próprias práticas.

A ideia de ler um cânone, como A hora da estrela, nesse formato que se deixa atravessar pelo estético e até pelo lúdico conduz-me a pensar que a concepção de leitura ali implícita passava longe dos aspectos tradicionais, ainda que não tenha se perdido no todo o valor prescritivo das atividades. Além disso, pode-se dizer que tanto minha posição de mediadora, quanto a que se esperava dos alunos foram se modificando ao longo desse período. É uma das noções que Annie Rouxel (2013) destaca nos avanços da pesquisa em didática da literatura, ou seja, a mudança de postura diante do texto, que antes se via como distanciada e objetiva e hoje já se percebe implicada, "sinal do engajamento do leitor no texto", uma "distância participativa" traduzida "por uma reabilitação do fenômeno de identificação, considerada durante muito tempo como uma regressão" (p. 19). Houve, então, o momento em que os alunos queriam ler porque se identificavam com a leitura e, não menos importante, enxergaram na minha função de porta-voz dessa leitura uma pessoa igualmente interessada em ler e - por que não? extasiada com a experiência.

É possível que a ideia de nomear de encontros as etapas deste projeto dissesse mais sobre minha própria implicação nas atividades, o reconhecimento de que ler literatura pode ser o desvio necessário para um ou muitos desses jovens que vivem em confinamento das próprias questões familiares, existenciais, sociais, culturais. O encontro com a literatura, mais precisamente com A hora da estrela, em nosso caso, permitiu certos balanços de nós mesmos e de nossas certezas. Petit (2013) destaca que nossa vida é repleta de movimentos que acontecem justamente por causa desses encontros:

O desejo de movimento pode provir também de encontros com lugares, com paisagens, com objetos diferentes, insólitos, em particular se tivermos a oportunidade de fazer uma viagem e deixarmos que o imprevisto se instaure. Ou pode provir de nossas leituras, nesses momentos em que as palavras topam com o que estava paralisado sobre uma imagem para lhe dar novamente vida [...] (p. 130).

A pouca experiência com didática da literatura levou-me, em vários momentos, a optar por uma abertura intuitiva: assim que enxergava a questão, consultava os alunos, buscava 
adequar as atividades àquela realidade nova ao meu olhar também novo. Mas tal disposição para outras possibilidades não precisa ficar apenas no plano da inexperiência. Quando lemos, somos capazes de estabelecer relações afetivas, emotivas e sensoriais com os livros, portanto, por que não ensinar o mesmo caminho aos nossos alunos? As tentativas e os "erros" são participantes e inevitáveis no contexto escolar e é importante ter isso em mente.

Mais uma vez, Petit (2009) defende que, para apropriar-se de um texto, há de haver contato com alguém, um mediador de leitura que desconstrói o objeto e encontra singularidade na voz. A leitura feita em voz alta, pausada, entonada e dialogada apareceu como um fator de apropriação e reinterpretação, talvez porque funcionasse como reelaboração estética do texto. É importante ressaltar, com isso, que minha preparação para a leitura em sala tornou-se valiosa, pois a performance dava o tom da prática. Por isso, além da atividade intelectual ali ativa, também se pode pensar nos aspectos afetivo, social e até corporal da leitura. Muitas vezes, os leitores-ouvintes disseram: "é bem mais fácil quando você lê junto com a gente, professora".

Mas, como se tornou claro, as dimensões da aprendizagem aqui descrita não ficam apenas no ângulo desses alunos, já que, como mediadora dessa prática, também construo e desconstruo minhas leituras. A ancoragem nas atividades de leitura parecia servir como condição para estabelecer o sentimento de pertencimento ao local e ao espaço escolar, de maneira que se criasse ali uma referência para as posteriores ideias relativas à leitura, como foi o caso de um grupo de alunos interessado em formar um clube de leitores ${ }^{7}$. Nesse sentido, assim como a leitura nunca era a mesma para cada uma dessas quatro turmas, segui também sendo metamorfoseada num espectro de múltiplas possibilidades.

\section{O que a leitura pode: deslocamentos}

A prática de falar sobre a própria leitura foi disseminada, principalmente, com o início da produção dos portfólios. Lembro aqui, novamente, de Bayard (2007), para quem os livros lidos e não lidos "formam uma espécie de segunda língua, à qual recorremos para falar de nós mesmos, para nos representar diante dos outros e para nos comunicarmos com os outros" (p. 150) - Rodrigo S.M. diz: "Porque há direito ao grito. Então eu grito" (LISPECTOR, 1995, p. 23). Para além disso, essa fomentação dos discursos sobre Macabéa foi um facilitador do

\footnotetext{
${ }^{7}$ Para saber mais, ver: SOARES, Sarah Vervloet. A escrita literária a partir de experiências no ensino médio. In: SOUZA, Renata Junqueira de et al. (Org.). In: Anais do V Congresso Internacional de Literatura Infantil e Juvenil CILJ/2017 - (Trans)formação de leitores: travessias e travessuras. Presidente Prudente: Ninfa Brisa Assessoria em Educação LTDA - ME, 2018, p. 32-43.
} 
processo de adesão de grande parte do grupo, funcionando como uma espécie de contaminação. As personagens passaram a nos ser íntimas. Macabéa virou Maca, por exemplo, para além do livro. E também verbo: "Professora, vamos macabear hoje?"; virou adjetivo: "macabeanos"; e hashtag nas redes sociais: \#Maca \#Macabéa \#macabeanos. E também: \#somosleitores. Uma aluna, baiana de origem, contou que seu namorado, também estudante daquela turma, passou a chamá-la, carinhosamente, de Macabéa. Se pensarmos que a leitura compartilhada foi decisiva para a ocorrência desses fatores, também podemos imaginar a "importância do contágio, da presença de professores ou adulto-chaves no descobrimento e apego à leitura" (COLOMER, 2007, p. 108).

Foram outros encontros além daqueles planejados - aliás, poderíamos falar de encontros consigo mesmos, encontros com suas sombras, seus medos, suas convicções etc. As contribuições de cada aluno para deixar os trabalhos com um estilo pessoal foram feitas por meio de diversas manifestações artísticas, como o desenho, a pintura, a música e... a literatura! São sujeitos: atores e autores de suas próprias histórias: "Eu que sou Macabéa quero aprender/ O que é esse mundo que só Deus vai saber, onde as pessoas são apressadas pra valer!”; "Ler A hora da estrela/ É como ficar louco sendo são/ Estar num manicômio interno/ Sendo o externo sempre a selva de pedra/ É sentir um crescente sem crescer/ Envoltos todos no vento/ Perdendose no tempo"; "Clarice não tinha medo de expressar seus pensamentos e os defendia com unhas e dentes. Me ensinou que 'até cortar os próprios defeitos pode ser perigoso. Nunca se sabe qual é o defeito que sustenta nosso edifício inteiro"”.

O desejo de buscar o cultivo das subjetividades levou o portfólio a uma qualidade pessoal, artística e identitária. Na perspectiva da educação literária ou leitura literária, podemos pensar numa ideia de permissão recíproca, que partiu de uma passagem aberta para variadas leituras possíveis, mas não teria progressão caso as portas não estivessem se abrindo ao longo desse percurso. Abaixo, é possível perceber algumas dessas produções: 
Imagem 2 - Capas dos portfólios
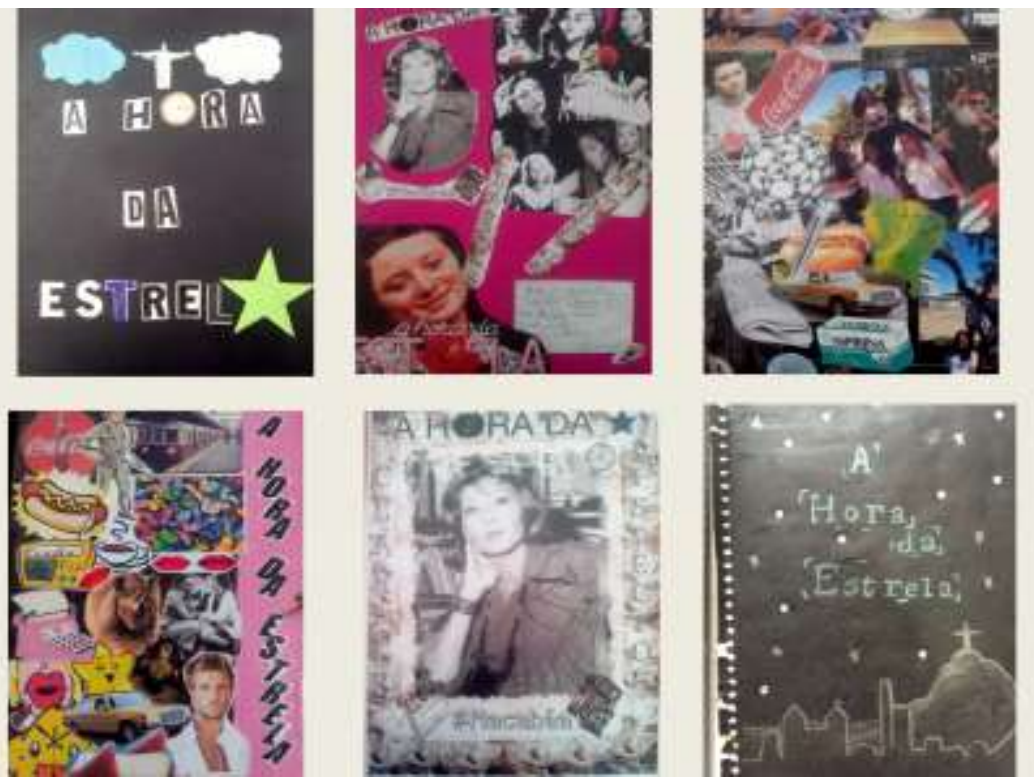

Fonte: da autora.

Imagem 3 - Criações autorais

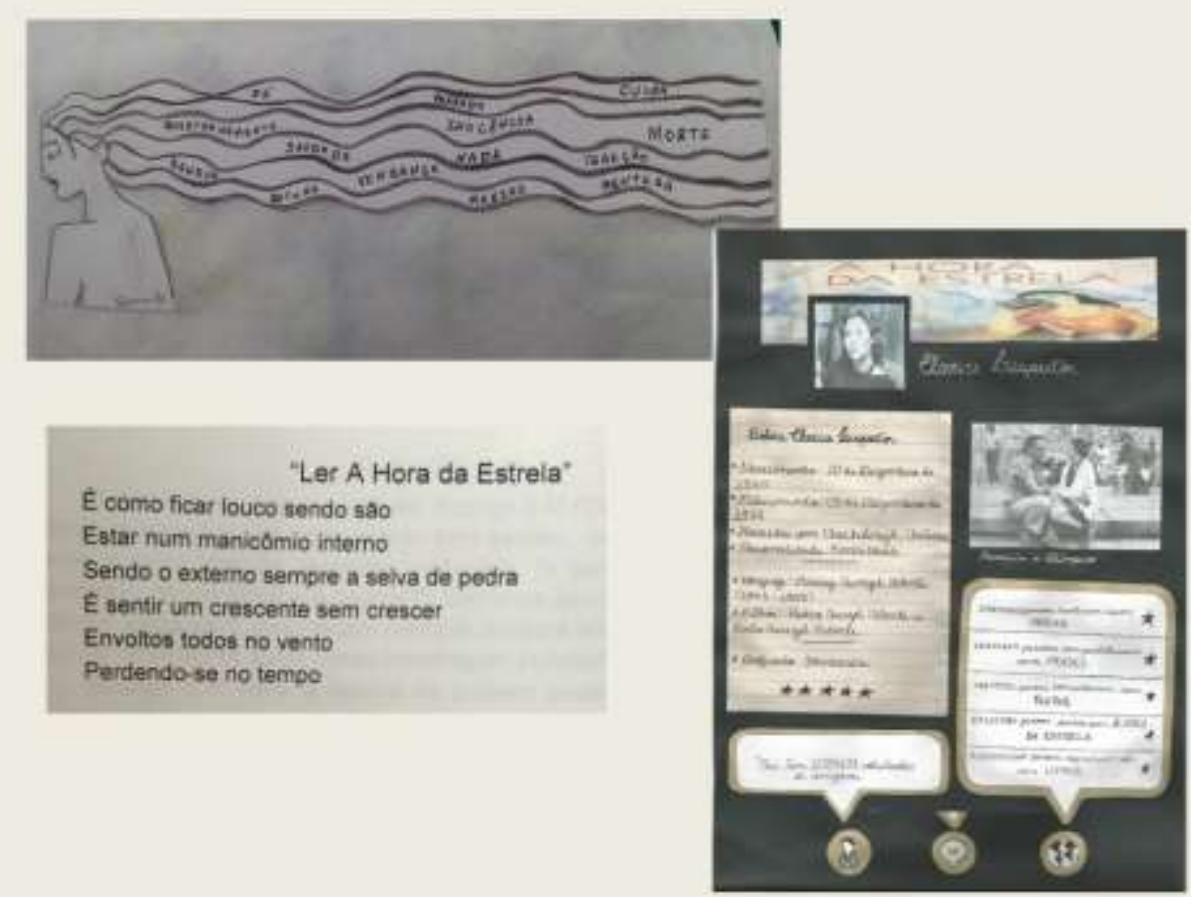

Fonte: da autora.

Nota: Na primeira figura, as palavras no cabelo de Macabéa: "passado", "culpa", "questionamento", "inocência", "saudade", "nada" etc.; logo abaixo, um poema de um aluno; ao lado, uma página de um portfólio que simulou o perfil de uma rede social para Clarice Lispector. 
E então o texto vai transformando-se em ressonâncias da própria vida, como uma aluna que interrompeu uma leitura em sala porque se recordou da história de sua família, descobrindose retirante como Macabéa, relembrando o que sua mãe fez para que ela e seus irmãos não sofressem de fome. Como afirma Langlade, "essa leitura participativa, longe de ser 'ingênua' e de diluir a obra em vagas referências ao vivido, está no fundamento mesmo da leitura literária" (LANGLADE, 2013, p. 37). Ela ali, de repente, também era Macabéa. Quando fala de experiências semelhantes, Petit (2009) ressalta:

[...] essas experiências [...] ajudam a despertar em uma pessoa regiões silenciadas ou enterradas no esquecimento, dar-lhes forma simbolizada, compartilhada, e transformá-las. Fundamentam a elaboração de uma história que desempenha um papel essencial na construção ou reconstrução de si mesmo, de uma narração sempre a retomar, sempre passível de ser recomposta, mesmo para quem as palavras faltam [...] (p. 105).

Há, nesse caso, uma leitura subjetiva que autoriza o aluno a ler conforme seus olhares e suas vivências, como afirmam Rouxel e Langlade (2013): “é impossível não reconhecer que o leitor real está no cerne de toda experiência viva da literatura, de toda apreensão sensível, ética e estética das obras" (p. 20). Assim, é possível permitir as leituras múltiplas e, mais do que isso, encorajar os alunos a serem críticos de suas leituras, mesmo que essa crítica seja restrita e confusa. É por isso que ambos os autores defendem uma análise da tensão entre os direitos do texto e os direitos do leitor (p. 21), os quais guardam a ideia de uma liberdade necessária e do também necessário respeito forçado às obras. Um malabarismo indispensável, mas ainda muito complexo de ser alcançado.

"Não importa quem você seja, você acaba se identificando com no mínimo uma das características de Macabéa”, um aluno registra no portfólio. Reconhecer-se em Macabéa parecia funcionar como aprender sobre si próprio, tanto na realidade de um passado miserável, quanto no sentimento desajustado com o mundo. Ao final das leituras, eu mesma compreendia certa manutenção do autoconhecimento naquele lugar que antes me era tão novo, e como diz um dos alunos, "talvez tenhamos uma outra interpretação do que é felicidade" ou a própria Clarice numa frase estampada em um dos portfólios: “Entender é uma questão de sentir". Podese dizer, então, que a leitura tornou-se experiência, os livros passaram a ter significados e "Isso não seria suficiente para modificar radicalmente a linha de seus destinos sociais, mas contribuiria para que evitassem certas armadilhas" (PETIT, 2009, p. 48). 


\title{
Considerações finais
}

O desfecho da história foi triste para muitos deles, como um grupo que veio até mim na sala dos professores para lamentar a morte de Macabéa. Alguns produziram no portfólio um final alternativo para a personagem. Outros se convenceram de que era o melhor que podia acontecer:

\begin{abstract}
As opiniões dos componentes do grupo ficaram divididas. Para os que gostaram, gostaram porque Maca não poderia ter um fim melhor. Seria fora da realidade se ela encontrasse alguém que gostasse dela de verdade, que ela ficasse esperta e se desse bem na vida. Com a morte ela encontrou a paz, virou uma estrela nem que seja por um minuto. Já para os que não gostaram, não gostaram pelo simples fato dela ter um fim trágico, pois ainda tinham esperança, nem que fosse mínima, que ela pudesse se tornar esperta, conseguisse se dar bem na vida e encontrasse uma pessoa que realmente gostasse dela. (Portfólio de leitura, 2014).
\end{abstract}

Podemos encontrar em um dos portfólios: "Macabéa morre, sentimos pena de macabéa, sim, o nome está em letra minúscula pois tal nome não pode ser dito como próprio”. Um aluno, um ano depois, afirmou: "nunca havia lido nenhum livro inteiro e, justamente quando resolvi fazer isso, essa tal de Macabéa morre no final". Quando perguntado se ele acredita que vai se esquecer desse livro, ele respondeu que, apesar de "não achar muita graça na história", "fazendo a leitura com a gente deu um melhor entendimento", "conseguimos imaginar a história e não só ler o livro". Talvez esse aluno nunca mais leia livro algum, mas conseguir "imaginar a história" parecia tão incomum a ponto de ser uma outra face da leitura, "não só leitura", mas imaginação, reinvenção, descoberta.

Ler junto, então, na esteira do "ensinar a fazer", pode programar um itinerário de aprendizagens, ainda que os alunos não consigam identificar de qual competência estamos falando. Em um dos portfólios, há um agradecimento à "grandiosa paciência" que tive com os alunos nos momentos de leitura. Para muitos deles, era disso que estávamos tratando: de paciência, de afeição, de cuidado. A leitura, como muitos deles registraram, "desenvolve a interpretação textual do leitor" e "deixa para todos nós uma lição". Como se, ao decidirem, por conta própria, comer cachorro-quente para falar de (e ser um pouco) Macabéa fosse apenas isso, mas eles percebiam de algumas formas: "Este livro é para pessoas que têm asas pregadas na cabeça, o voo é lento, mas é belo".

Assim, a ideia de expor os trabalhos finais dos alunos na biblioteca foi uma importante finalização, ou melhor, extensão do projeto (ver imagem abaixo). Ainda que as prateleiras que expunham os portfólios não mostrassem o caminho percorrido, a relação mantida com a biblioteca foi especial, pois voltávamos para o ponto de partida, e transformados. O diálogo 
com a biblioteca foi significativo para repensar as atividades de sala e a exposição terminou por ser uma forma de avaliação dos alunos consigo mesmos. Afinal, uma das grandes contribuições que o projeto trouxe foi pensar nos mecanismos utilizados para avaliação desses processos. É nesse sentido que Bayard (2007) critica o espaço escolar como espaço de violência que marca a leitura com a lógica do verdadeiro e falso, como se fosse possível avaliar segundo critérios dos quais ela própria não dá conta.

Imagem 4 - Exposição na biblioteca

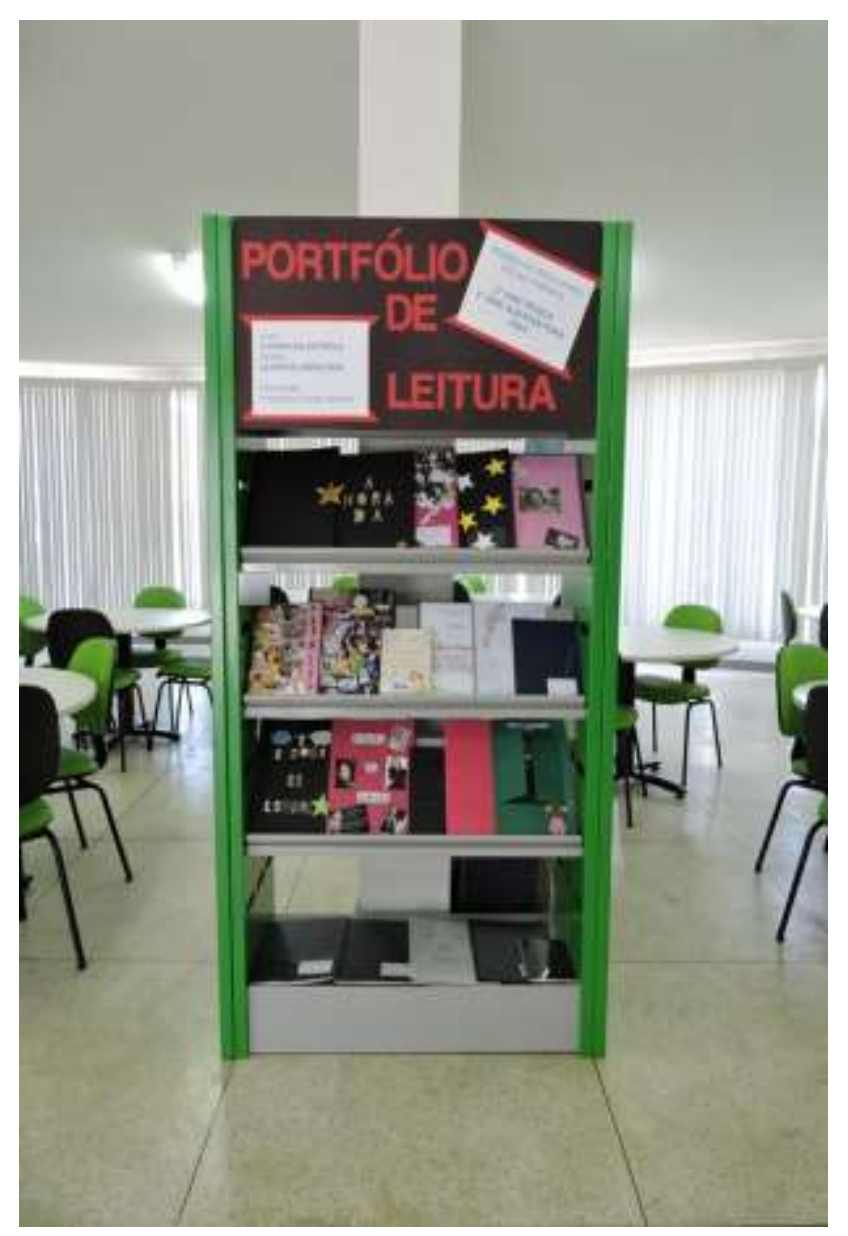

Fonte: da autora.

Embora não sendo completamente livre, a leitura foi uma experiência singular para muitos desses alunos. Parece indispensável que se pense na literatura como processo humanizador do indivíduo e, por isso, ela deve ser encarada como um direito, como defende Antonio Candido (2011). Legitimar as práticas de leitura literária são, então, uma maneira de contribuir para a constituição de um sujeito autônomo, ainda que este seja instável, mutante e esteja imerso nas transformações. Foram quase unânimes os registros do portfólio que traziam 
críticas àquela literatura em algum momento de leitura, referindo-se a sua "complexidade", às "palavras difíceis", ao "narrador um pouco chato", bem como a um "P.S.: Não gostei do jeito de Clarice escrever". E as conclusões curiosas ao final, como "leia o livro, mesmo que pareça difícil". Três anos depois, quando questionados sobre o que guardavam da leitura de A hora da estrela, permanece a mesma ideia de que a história de Macabéa é difícil de entender, mas um fator chama atenção: "O modo como você leu com a gente foi essencial, pois só depois de começarmos a ler que iríamos querer terminar"; "Nunca tinha lido clássicos antes e o fato de ter lido A hora da estrela me fez querer ler mais clássicos brasileiros"; "gostei muito do momento de leitura, fez com que a gente tivesse interesse de ler"; "Achei o método de ler com a gente muito eficiente porque tornou a leitura mais leve, uma vez que o vocabulário e expressões não compreendidas eram esclarecidas. Isso facilitou muito, além de tornar tudo mais poético".

A difusão das obras literárias por meio de uma condução mediada, num primeiro momento, pode contribuir para o crescimento e amadurecimento desses leitores. Como se os pontos falsos que surgem nesse percurso ligassem, de fato, as bordas do incompreensível. Não são falsos porque não existem, mas porque a leitura literária na escola não é capaz de fazer milagres, apesar de poder suturar as esperanças e religar os sentidos. Torna-se vital ultrapassar, então, os limites do que é bom, belo e edificante, para compreender que estar nos meandros das possibilidades de leitura promove experiências transformadoras.

\section{Referências}

BARROS, M. H. T. C.; BORTOLIN, S.; SILVA, R. J. Leitura: mediação e mediador. São Paulo: FA, 2006.

CANDIDO, Antonio. O direito à literatura. In.: Vários escritos. $5^{\mathrm{a}}$ ed. Rio de Janeiro: Ouro sobre Azul, 2011, 169-191.

COLOMER, Teresa. Andar entre livros: a leitura literária na escola. Trad. Laura Sandroni. São Paulo: Global, 2007.

JAUSS, Hans Robert. A história da literatura como provocação à teoria literária. Trad. Sérgio Tellaroli. São Paulo: Ática, 1994, p. 5-57.

LANGLADE, Gérard. O sujeito leitor, autor da singularidade da obra. Trad. Rita JoverFaleiros. In.: ROUXEL, Annie; LANGLADE, Gérard; REZENDE, Neide Luzia de. Leitura subjetiva e ensino de literatura. Trad. Amaury C. Moraes et al. São Paulo: Alameda, 2013, p. $25-38$.

LISPECTOR, Clarice. A hora da estrela. 23ª edição. Rio de Janeiro: Francisco Alves, 1995. 
PETIT, Michèle. Os jovens e a leitura: uma nova perspectiva. Trad. Celina Olga de Souza. São Paulo: Ed. 34, 2008.

A arte de ler. Ou como resistir à adversidade. Trad. Arthur Bueno e Camila Boldrini. São Paulo: Editora 34, 2009.

Leituras: do espaço íntimo ao espaço público. Trad. Celina Olga de Souza. São Paulo: Editora 34, 2013.

REZENDE, Neide Luzia de. O ensino de literatura e a leitura literária. In.: DALVI, Maria Amélia; REZENDE, Neide Luzia de; JOVER-FALEIROS, Rita (Orgs.). Leitura de literatura na escola. São Paulo: Parábola, 2013, p. 99-112.

ROUXEL, Annie. Aspectos metodológicos do ensino da literatura. Trad. Neide Luzia de Rezende. In.: DALVI, Maria Amélia; REZENDE, Neide Luzia de; JOVER-FALEIROS, Rita (Orgs.). Leitura de literatura na escola. São Paulo: Parábola, 2013, p. 17-33.

ROUXEL, Annie; LANGLADE, Gérard. Apresentação dos coordenadores franceses. In.: ROUXEL, Annie; LANGLADE, Gérard; REZENDE, Neide Luzia de. Leitura subjetiva e ensino de literatura. Trad. Amaury C. Moraes et al. São Paulo: Alameda, 2013, p. 19-24.

Recebido em: 10/12/2018 Aceito para publicação em: 17/03/2019 